
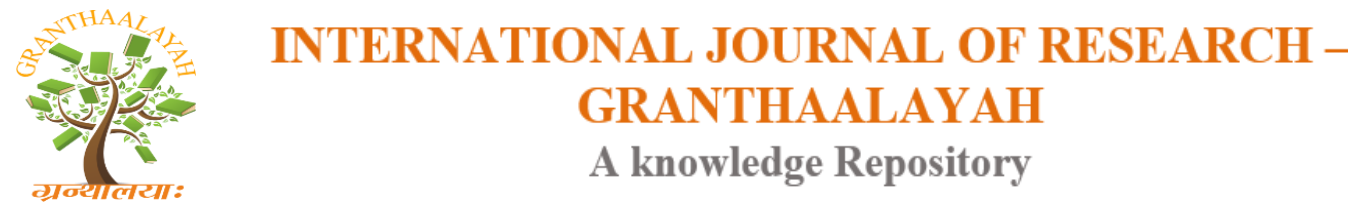

Science

\title{
NET NEWS READING HABIT AMONG ARTS AND SCIENCE COLLEGE
} STUDENTS

\author{
Dr. N. Ramakrishnan ${ }^{* 1}$, Mrs. J. Johnsi Priya ${ }^{2}$ \\ ${ }^{* 1}$ Professor and Head, Dept. of Educational Technology, Tamil Nadu Teachers Education \\ University, Chennai- 600 097, INDIA \\ ${ }^{2}$ Assistant Professor of Mathematics Education, Measi College of Education, Choolai, Chennai, \\ INDIA
}

DOI: https://doi.org/10.29121/granthaalayah.v4.i9(SE).2016.2509

\begin{abstract}
Net news is more vivid and quick. It comes with audio video clippings. It is livelier than printed newspaper. Net news have galaxy of items to read on. It can be read anywhere and at any time provided one has android, windows or ios smart phones with net card or laptop with data card or dongle. News has a wide variety of things be it education, political, social, cultural, economy, entertainment and so on. Regular reading of news in net enhances the worldly knowledge of students. But how far our younger generations have developed the habit of reading net news is the question raised in our minds. Reading news in net would enhance the General Knowledge and current worldly affairs of a student. Net news reading makes a man informative. Hence, the present topic has been chosen as Net news reading habits of Arts and Science College students. The study has used questionnaire for finding out net news reading habit among arts and science college students. The investigator has collected a sample of 200 arts and science college students from Madurai. The investigator has used stratified random sampling technique for the present study. The findings of the study reveals that the arts and science college students $2 \%$ of them read daily, $8 \%$ of them read weekly once and $22 \%$ of them read monthly once and $68 \%$ of them read net news occasionally.
\end{abstract}

Keywords:

Net News, Reading habits, Arts and Science College students.

Cite This Article: Dr. N. Ramakrishnan, and Mrs. J. Johnsi Priya, "NET NEWS READING HABIT AMONG ARTS AND SCIENCE COLLEGE STUDENTS", International Journal of Research - Granthaalayah, Vol. 4, No. 9: SE (2016): 50-56.

\section{INTRODUCTION}

News is very important for a person to know what is happening in and around the world. It makes him informed about his surroundings. News in the beginning was through public 
announcements using drum. Later it has developed into hand written copies. During freedom struggle of India, our freedom fighters have used handwritten newspapers to spread the message. Then Print media played a vital role in spreading knowledge and sharing information. Now it has gone beyond print. Electronic media has occupied the prime place. For example Tamil dailies like are Dina Thanthi, Dinakaran, Dinamani, and Dinamalar have net newspapers. The other language papers also have their own net based newspapers. The service providers like Yahoo and others are also having news item in their portal. Subscribers to these newspapers are on the rise. It is helping the overseas people mainly. Irrespective of the place where we are living we can have a glance over our favourite newspaper through net. The news in net is more vivid as it comes sometimes with audio and video clippings. The images are crystal clear when we see in net. It is livelier than printed newspaper. Net news have galaxy of items to read on. It can be read anywhere and at any time provided one has android, windows or ios smart phones/tablets/ipads/laptops/desktops with internet connectivity. News has a wide variety of things be it education, political, social, cultural, economy, entertainment and so on. Regular reading of news in net enhances the worldly knowledge of students. But how far our younger generations have developed the habit of reading net news is the question raised in our minds. Reading news in net would enhance the general knowledge and current worldly affairs of a student. Net news reading makes a man more informative. Hence, the present topic has been chosen as Net news reading habits of Arts and Science College students.

\section{TERMS AND DEFINITIONS}

Net News - refers to information provided in Internet.

Reading Habits- refers to behaviour of appraising information provided in Net news

Arts and Science College students - refers to one who is studying B.A. or B.Sc. in Arts and Science Colleges.

\section{OBJECTIVES OF THE STUDY}

1) The study has formulated the following objectives:

2) To find out the frequency in reading Net news by arts and science College students.

3) To find out the length of Net news reading habits among arts and science college students.

4) To find out the mode adopted by arts and science colleges students for Net news reading.

\section{HYPOTHESES FORMULATED FOR THE STUDY}

The hypotheses have been stated in null form:

1) The arts and science college students do not have any frequency in reading Net news.

2) The arts and science college students do not have any length of Net news reading habits.

3) The arts and science college students do not have any specific mode for reading Net news.

\section{INSTRUMENTATION}

The investigator has consulted experts in the media field and professors in the Journalism Department of Madurai Kamaraj University for the construction of questionnaire on Net news 
reading habit. After having repeated discussion with the experts, the investigator finalized a tool with 20 items.

\section{ESTABLISHMENT RELIABILITY OF THE TOOL}

\section{TEST AND RETEST METHOD}

The questionnaire was administrated among the 40 arts and science college students and re administrated among the same 40 arts and science college students after a gap of 15 days. The correlation found for the item frequency of reading Net news between the two successive administrations of the questionnaire was 0.73. It is high correlation. Hence it is assumed that the questionnaire is having reliability. Thus the reliability of the rating scale was ensured.

\section{ESTABLISHING VALIDITY OF THE TOOL}

The investigator has consulted experts in the department of journalism and mass communication of Madurai Kamaraj University for constructing the tool. It ensures face and content validity of the questionnaire.

According, to Garret, H.E (1967, P, 365) the index of reliability is sometimes taken as a measure of validity.

\section{SCORING}

The frequency of Net news reading was given rating like 1,2, 3 and 4 for the responses daily, weekly once, monthly once and occasionally. The other items were counted and percentage was worked out.

\section{SAMPLE DESIGN}

The investigator has followed random sampling method for the present study. The investigator has collected a sample of 200 arts and science college students in Madurai city.

\section{NEWSPAPER READING HABITS AMONG HIGH SCHOOL STUDETNS}

Net news reading habits among arts and science college students are presented in percentage form in Table 1. The details regarding null hypotheses stated and decisions regarding the hypotheses are presented in the following paragraphs.

\section{HYPOTHESIS 1:}

The arts and science college students do not have any frequency in reading Net news.

The details regarding the frequency of reading Net news by arts and science college students are presented in the following Table 1. 
Table 1: PERCENTAGE ANALYSIS FOR THE FREQUENCY IN READING NET NEWS

\begin{tabular}{|l|l|l|l|}
\hline Sl. No & Time & No. of students & Percentage \\
\hline 1. & Daily & 4 & 2 \\
\hline 2. & Weekly Once & 16 & 8 \\
\hline 3. & Monthly Once & 44 & 22 \\
\hline 4. & Occasionally & 136 & 68 \\
\hline & Total & 200 & 100 \\
\hline
\end{tabular}

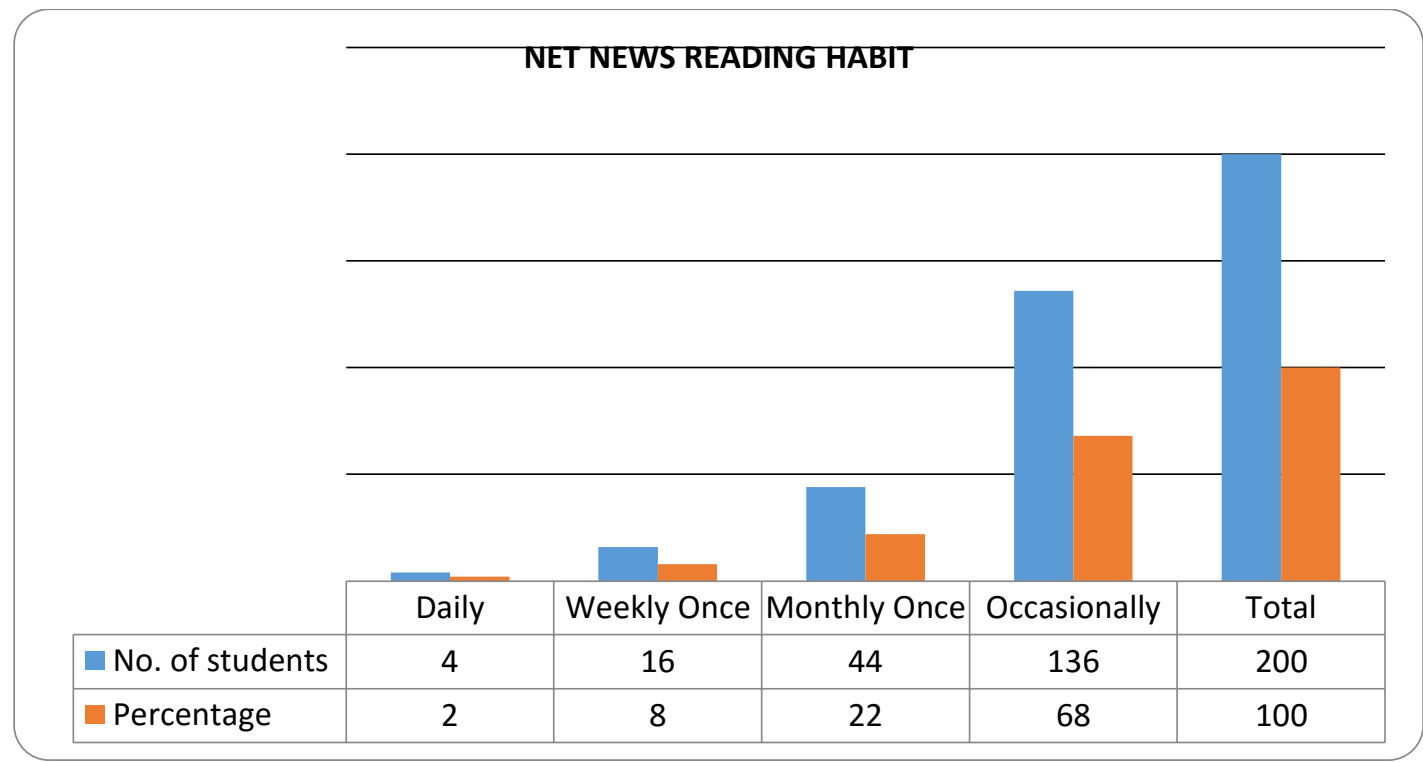

Figure 1: PERCENTAGE ANALYSIS FOR THE FREQUENCY IN READING NET NEWS

It is evident from Table 1 that the arts and science college students $2 \%$ of them read Net news daily, $8 \%$ of them read weekly once, $22 \%$ of them read monthly once and $68 \%$ of them read Net news occasionally.

It may be concluded from the above table that $68 \%$ of arts and science college students read Net news occasionally, $22 \%$ of them monthly once, $8 \%$ read weekly and $2 \%$ of them read monthly once.

\section{HYPOTHESIS 2:}

The arts and science college students do not have any length of Net news reading habits.

The details regarding the length of Net news reading habits among arts and science college students are presented in the following Table 2. 
Table 2: PERCENTAGE ANALYSIS FOR THE LENGTH IN READING NET NEWS

\begin{tabular}{|l|l|l|l|}
\hline Sl.No. & Time & No. of students & Percentage \\
\hline 1. & Less than one year & 152 & 76 \\
\hline 2. & One to three years & 36 & 18 \\
\hline 3. & More than three years & 12 & 6 \\
\hline & Total & 200 & 100 \\
\hline
\end{tabular}

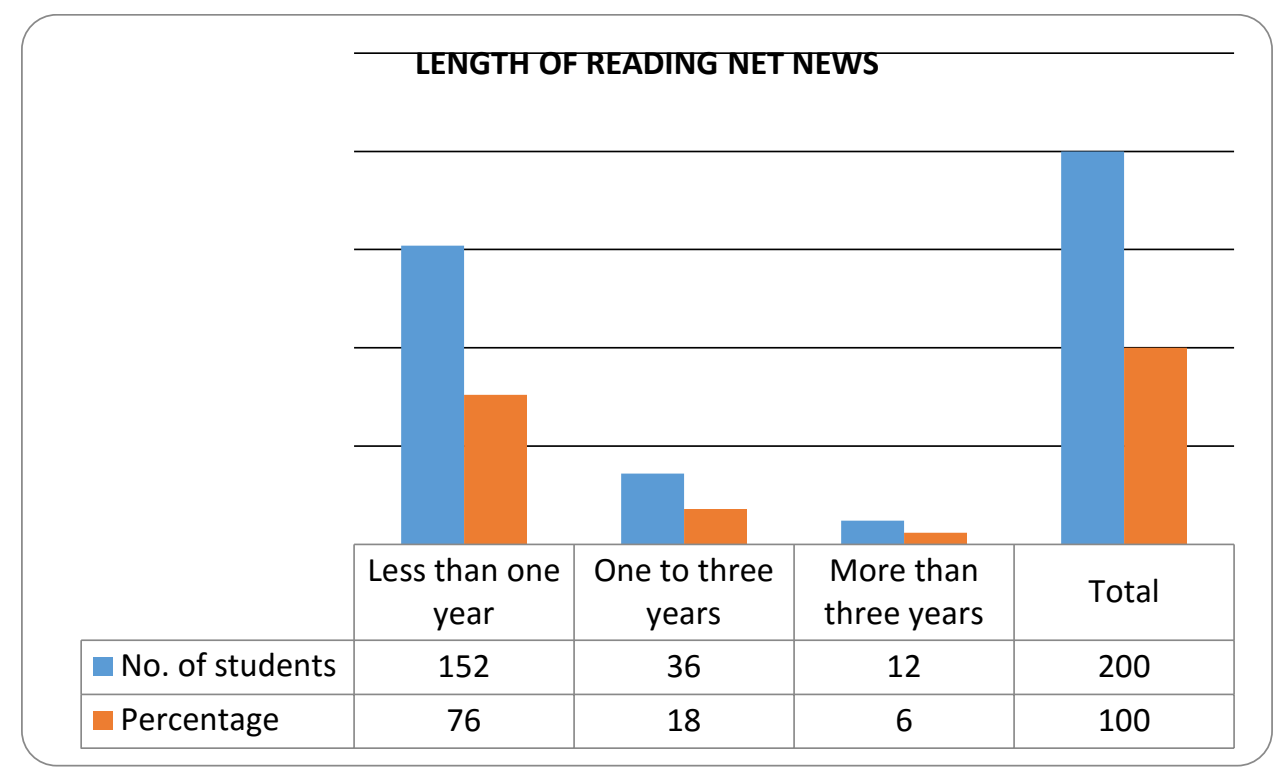

Figure 2: PERCENTAGE ANALYSIS FOR THE LENGTH IN READING NET NEWS

It is evident from Table 2 that $76 \%$ of arts and science college students read Net news less than one year. $18 \%$ of them read Net news one to three years. $6 \%$ of them have the Net news reading habit of more than three years.

It can be concluded from the above Table that the majority of arts and science college students have started reading Net news less than one year. 18\% of them read Net news one to three years. $6 \%$ of them read Net news more than three years.

\section{HYPOTHESIS 3:}

The arts and science college students do not have any specific mode for reading Net news.

The details regarding the mode of reading Net news among arts and science college students are presented in the following Table 3.

Table 3: PERCENTAGE ANALYSIS FOR THE MODE OF NET NEWS READING AMONG ARTS AND SCIENCE COLLEGE STUDENTS

\begin{tabular}{|l|l|l|l|}
\hline SI.No. & Place & No. of students & Percentage \\
\hline 1. & $\begin{array}{l}\text { Smart Phones } \\
\text { ( Windows, Ios and Android) }\end{array}$ & 82 & 41 \\
\hline 2. & Tablets / ipads & 37 & 18.5 \\
\hline
\end{tabular}




\begin{tabular}{|l|l|l|l|}
\hline & ( Windows, Ios and Android) & & \\
\hline 3. & Laptops & 54 & 27 \\
\hline 4. & Desktops & 27 & 13.5 \\
\hline & Total & 200 & 100 \\
\hline
\end{tabular}

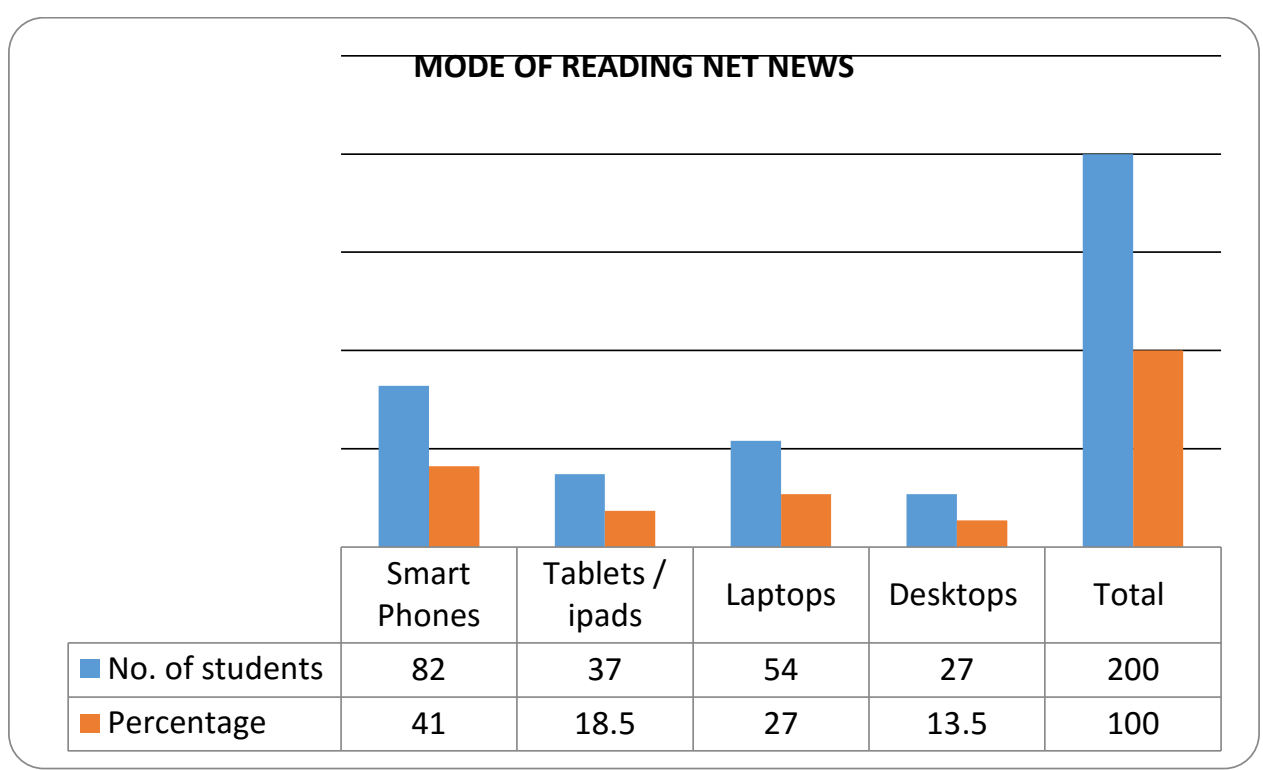

Figure 3: PERCENTAGE ANALYSIS FOR THE MODE OF NET NEWS READING HABIT AMONG ARTS AND SCIENCE COLLEGE STUDENTS

It is evident from Table 3 that the high school students $41 \%$ of them read Net news through smart phones, $18.5 \%$ of them read Net news through tablets / I pads, $27 \%$ of them read Net news through laptops, $13.5 \%$ of them read Net news through desktops.

It may be concluded from the above table that majority of arts and science college students read Net news through smart phones, $27 \%$ of them read Net news through laptops, $18.5 \%$ of them read Net news through tablets/ I pads and $13.5 \%$ of them read Net news through desktops.

\section{CONCLUSION}

The study can be concluded by stating the following. They are:

1) It is revealed from the study that $68 \%$ of arts and science college students read Net news occasionally, $22 \%$ of them monthly once, $8 \%$ read weekly and $2 \%$ of them read monthly once.

2) It is proved in this study that the majority of arts and science college students have started reading Net news less than one year. $18 \%$ of them read Net news one to three years. $6 \%$ of them read Net news more than three years.

3) It is exposed in this study that majority of arts and science college students read Net news through smart phones, $27 \%$ of them read Net news through laptops, $18.5 \%$ of them read Net news through tablets/ I pads and $13.5 \%$ of them read Net news through desktops. 


\section{EDUCATIONAL IMPLICATIONS}

It is revealed from the study that majority of arts and science college students read Net news occasionally. It may be due to availability of smart phones/ tablets/ laptops/desktops. It may be due to internet connectivity. It is proved in this study that the majority of arts and science college students have started reading Net news less than one year. Citizens are becoming netizens recently. Rapid changes in the behavior of students are recent as service providers like Tata docomo/ Aircel/ Airtel/ BSNL made vigorous campaigns for net packs. It is exposed in this study that majority of arts and science college students read Net news through smart phones. This finding is due to many new smart phones which are coming up in the market with competitive prices.

\section{REFERENCES}

[1] Alasuutari, Pertti. 1995. Researching Culture: Qualitative Method and Cultural Studies.

[2] Altschull, J. Herber. 1990. From Milton to Mcluhan: The Ideas Behind American Journalism. White Plains, N.Y.: Longman.

[3] Aquinas, St. Thomas. 1272 (1966). Treatise on the Virtues. Translated by J. A. Oesterle. Notre Dame, IN: University of Notre Dame Press.

[4] ASNE. 1999. Leveraging Newspaper Assets [Web archive]. American Society of Newspaper Editors, Oct. 121998 [cited June 18 1999].

[5] Assael, Henry. 1987. Consumer Behavior and Marketing Action. Third ed. Boston: PWSKent Publishing.

[6] Ball-Rokeach, Sandra J. 1985. The Origins of Individual Media-System Dependency: A Social Framework. Communication Research 12 (4):485-510.

[7] Ball-Rokeach, Sandra J., and Melvin DeFleur. 1976. A Dependency Model of Mass Media Effects. Communication Research 3:3-21.

[8] Barnhurst, Kevin G., and Ellen Wartella. 1991. Newspapers and Citizenship: Young Adults' Subjective Experience of Newspapers.

[9] Bauer, Raymond A. 1963. The Initiative of the Audience. Journal of Advertising Research 3:2-7.

[10] Baukus, Robert A. 1999. Perception of Mediated Social Conflict: Media Dependency and Involvement. In Framing Friction, edited by M. S. Mander. Urbana: University of Illinois Press.

[11] Beam, Randal A. 1995. How Newspapers Use Readership Research. Newspaper Research Journal 16 (1):28(11).

[12] Golden, S. A. R. (2011). Problems and Prospectus of Distance Learning. Bharathidhasan University, 343, 344.

[13] Golden, S. A. R. (2011). Strategy For Success Of Human Beings:-Time Management.

[14] Golden, S. A. R., \& Regi, S. B. (2013). Mobile Commerce in Modern Business Era. International Journal of Current Research and Academic Review, 1(4), 96-102. 